Тарасенко ИеонlА МеонІдович,

канАиАат юриАичних наук, аАвокат, Аоцент кафедри інтелектуальної власності, інформаційного та корпоративного права юридичного факультету ^ьвівського національного університету імені Івана Франка

\title{
НОВАЦІЇ ЩОДО ЗДІЙСНЕННЯ КОЛЕКТИВНОГО УПРАВЛІННЯ МАЙНОВИМИ АВТОРСЬКИМИ ТА СУМІЖНИМИ ПРАВАМИ
}

Постановка проблеми. У мипні 2018 р. набув чинності Закон України «Про ефективне управління майновими правами правовласників у сфері авторського права і (або) суміжних прав" (Аалі - Закон про ефективне управління правами). Цей Закон визначає правові та організаційні засади колективного управління майновими правами суб'єктів авторського права й (або) суміжних прав в Україні. Закон кардинально змінив засади колективного управління правами.

Закон передбачає новий механізм набуття правового статусу організації колективного управління (Аалі - ОКУ). Окрім того, Аіючі ОКУ продовжують зАійснювати свою Аіяльність лише у визначених цим Законом часових межах.

ОАнак станом на сьогодні залишається не Ао кінця визначеним правовий статус Аіючих ОКУ, які внесені у “старий" реєстр ОКУ. Ця невизначеність породжує неоднакове правозастосування на практиці у віАносинах між ОКУ та юридичними особами (власниками бізнесу), які здійснюють використання музичних творів піА час зАійснення господарської Аіяльності. ІАеться про можливість правомірного використання так званої "фонової" музики. Зокрема, правовим механізмом такого законного використання музичних творів мало б бути укладення ліцензійного (або іншого) Аоговору між ОКУ (або прямо з правовласниками) і юриАичною особою (фізичною особою-піАприємцем). Водночас сьогодні преАставники бізнесу (користувачі музичних творів) не розуміють, із ким вони можуть укласти такий договір. ОКУ, які Аіяли Ао прийняття Закону про ефективне управміння правами, вже або не наділені такими правами, або наділені окремими з них мише до певного часу. ОКУ, які внесені в новий реєстр ОКУ
віАповіАно Ао вимог нового Закону про ефективне управління правами, також не набули ще повної правової визначеності щодо своїх можливостей.

Стан АосліАження теми. У науковій літературі практично віАсутні АосліАження $з$ указаної проблематики. На рівні монографічних і дисертаційних досліджень також указана проблематика ще не проаналізована в силу невеликого проміжку часу після суттєвих законодавчих змін АосліАжуваних віАносин.

Метою статті $€$ характеристика законодавчих новацій щодо зАійснення колективного управління майновими авторськими та суміжними правами, обґрунтування пропозицій щодо вАосконалення правового регулювання цих віАносин.

ВикиаА основного матеріалу АосліАження 3 повним обгрунтуванням отриманих наукових результатів. ВіАповіАно Ао п. 2 Прикінцевих та перехілних положень Закону про ефективне управління правами, свіАоцтва про облік організацій колективного управління, про визначення організацій колективного управління уповноваженими, про уповноваження організацій колективного управління, виАані до набрання чинності цим Законом, утрачають чинність через Аев'ять місяців з дня набрання чинності цим Законом, а у сферах, щодо яких Закон передбачає здійснення розширеного та обов'язкового колективного управління, - з оголошеної Установою віАповідно Ао частини четвертої статті 15 цього Закону Аати закінчення прийому заяв на участь у конкурсі на акреАитацію у віАповідній сфері. Після втрати чинності свідоцтва про облік організацій колективного управління, про визначення організацій колективного управління уповноваженими, про уповноваження організацій юридичні особи, 
які не були включені до Реєстру організацій колективного управління в порядку, визначеному цим Законом, зобов'язані вчинити Аії, передбачені частиною четвертою статті 18 цього Закону.

Аатою набуття чинності Законом про ефективне управління правами є 22.07.2018. Свідоцтва ОКУ втрачають чинність через 9 місяців з Аня набрання чинності Законом, тобто 22.04.2019. Водночас законодавець установив певні винятки з указаного правила. Зокрема, у сферах, щодо яких Закон передбачає здійснення розширеного та обов'язкового колективного управління, свіАоцтва ОКУ втрачають чинність - з оголошеної Установою (йдеться про МЕРТ України), віАповіАно Ао частини четвертої статті 15 цього Закону, Аати закінчення прийому заяв на участь у конкурсі на акредитацію у віАповіАній сфері.

Аля тлумачення змісту вказаної норми варто вказати, що видами колективного управління $€$ Аобровільне, розширене та обов'язкове.

Аобровільне колективне управління зАійснюЄться ОКУ викАючно щОАО Об'єКтів авторського права й (або) суміжних прав, вк^ючених Ао катамогу віАповіАної організації колективного управ^іння. Аобровільне колективне управління майновими авторськими та суміжними правами може заійснюватися в будь-якій сфері управління правами, крім тих, у яких зАійснюється розширене або обов'язкове колективне управління. Про це вказано в ч. 4 ст. 12 Закону про ефективне управАіння правами.

Розширене колективне управління майновими правами на об'єкти авторського права й (або) суміжних прав зАійснюється ОКУ незалежно віА їх наявності в каталозі ОКУ (крім випадків, коли віАповіАні права вилучені правовласником з колективного управління в порядку, встановленому законом порядку) у визначених Законом про ефективне управління правами сферах, що зАійснюється акредитованими Установою організаціями у визначених законом сферах.

Розширене колективне управління поширюється на всю територію України та зАійснюється щодо майнових прав усіх правовласників за віАповіАною категорією у сферах, щодо яких акредитовано організацію, у тому числі тих, що не укладали Аоговір про управління об'єктами авторського права й (або) суміжних прав $з$ акреАитованою організацією, незалежно віА обраного такими правовласниками способу управління належними їм правами.

Розширене колективне управління передбачає також право правовласників вилучати пов- ністю або частково належні їм права на об'єкти авторського права й (або) суміжних прав з управління акредитованої організації колективного управління в порядку, передбаченому законом. Це важливе майнове авторське (суміжне) право, яким наділяються суб'єкти авторського права та суміжних прав.

Законодавець визначив вичерпний перелік сфер розширеного колективного управління об'єктами авторського права й (або) суміжних прав. Ао них належать такі:

1) публічне виконання музичних недраматичних творів з текстом і без тексту включно з тими творами, що включені до складу аудіовізуальних творів;

2) публічне сповіщення музичних неАраматичних творів з текстом і без тексту включно з тими творами, що включені Ао складу аудіовізуальних творів, крім кабельної ретрансляції;

3) право на справеАливу винагороду, спільну Аля виконавців і виробників фонограм (відеограм), за публічне виконання фонограм і зафіксованих у них виконань чи публічну демонстрацію відеограм і зафіксованих у них виконань, опублікованих Аля використання з комерційною метою;

4) право на справедливу винагороду, спільну Аля виконавців і виробників фонограм (відеограм), за публічне сповіщення фонограм і зафіксованих у них виконань, відеограм і зафіксованих у них виконань, опублікованих Аля використання з комерційною метою, крім кабельної ретрансляції.

За кожною сферою розширеного колективного управління визначається одна акредитована організація, але за умови, що віАсутні будь-які конфлікти інтересів між основною категорією правовласників, в інтересах якої діє така організація, та іншими категоріями правовласників, на користь яких має збиратися АохіА віА прав у віАповіАній сфері розширеного колективного управління.

У разі існування зазначеного конфлікту інтересів може бути визначено додаткову акредитовану організацію Аля цієї сфери 3-поміж організацій, які зАійснюють Аіяльність переважно в інтересах відповіАної іншої категорії правовласників. Ця організація не має права самостійно здійснювати збір доходу віА прав з користувачів у віАповіАній сфері, але водночас має повноваження вимагати й отримати 3 акредитованої організації частку Аоходу віА прав у цій сфері, яка належить категорії правовласників, в інтересах яких діє додаткова акредитована організація, Аля подальшого розпоАілу та виплати такої частки правовласникам цієї категорії. Правовласники віАповідної категорії 
мають право відкликати свої права з додаткової акредитованої організації віАповідно до розширеного колективного управління.

Законодавець Аопускає, що одна організація колективного управління може бути акредитована на зАійснення розширеного колективного управління в Аекількох сферах щодо Аекількох категорій правовласників за умови відсутності конфлікту інтересів між різними категоріями правовласників.

Обов'язкове колективне управління майновими правами на об'єкти авторського права й (або) суміжних прав зАійснюється ОКУ незалежно віА їх наявності в каталозі ОКУ. Така ОКУ також повинна бути акредитованою Комісією з акредитації ОКУ у визначених законом сферах.

Обов'язкове колективне управління поширюється на всю територію України та зАійснюється щодо майнових прав усіх правовласників за віАповідною категорією у сферах, щодо яких акреАитовано організацію. Важливим $є$ те, що таке управління зАійснюється і щодо майнових прав тих правовласників, які не укладали договір про управління об'єктами авторського права й (або) суміжних прав з акредитованою організацією, незалежно віА обраного такими правовласниками способу управління належними їм правами.

Обов'язкове колективне управління об'єктами авторського права й (або) суміжних прав зАійснюється виключно в таких сферах:

1) право слідування щодо творів образотворчого мистецтва;

2) репрографічне відтворення творів і їх частин (уривків);

3) відтворення в Аомашніх умовах і в особистих цілях творів, виконань, зафіксованих у фонограмах, відеограмах, їх примірниках, а також аудіовізуальних творів і їх примірників;

4) кабельна ретрансляція об'єктів авторського права й (або) суміжних прав, крім прав організацій мовлення щодо їхніх власних програм (переАач) мовлення.

Перелік сфер колективного управління, за якими зАійснюється обов'язкове колективне управління, знову ж таки є вичерпним.

Важливо, що за кожною сферою обов'язкового колективного управління визначається оАна акредитована організація. Але можливим є варіант, що одна ОКУ може бути акредитована на зАійснення обов'язкового колективного управміння в Аекількох сферах, а також одночасно зі зАійсненням розширеного колективного управміння.
Обов'язкове колективне управління, на віАміну віА розширеного, не передбачає вилучення правовласником, повністю або частково, належних йому майнових прав з управління акредитованою організацією.

Отже, на основі вищенаведених положень Закону про ефективне управління правами можна зробити такі висновки.

Аобровільне колективне управління не може зАійснюватися ОКУ після 22.04.2019, бо закон містить припинювальний строк утрати чинності Свідоцтва в цій сфері. Така Аіяльність може зАійснюватися тільки ОКУ, які внесені в новий реєстр OKY.

Станом на сьогодні Мінекономрозвитку розмістило оголошення про початок віАкритого конкурсу Аля визначення акредитованих організацій колективного управління у сферах:

1. Розширене колективне управління:

- право на справедливу винагороду, спільну Аля виконавців і виробників фонограм (відеограм), за публічне виконання фонограм і зафіксованих у них виконань чи публічну демонстрацію відеограм і зафіксованих у них виконань, опублікованих Аля використання з комерційною метою;

- право на справедливу винагороду, спільну Аля виконавців і виробників фонограм (відеограм), за публічне сповіщення фонограм і зафіксованих у них виконань, відеограм і зафіксованих у них виконань, опублікованих Аля використання з комерційною метою, крім кабельної ретрансляції.

2. Обов'язкове колективне управління:

- право слідування щодо творів образотворчого мистецтва;

- кабельна ретрансляція об'єктів авторського права й (або) суміжних прав, крім прав організацій мовлення щодо їхніх власних програм (переАач) мовлення.

Аокументи приймалися до 24 квітня 2019 року. Отже, у цих чотирьох сферах з 25.04.2019 Аіючі OKУ (які не перебувають у новому реєстрі OKУ) вже не мають права здійснювати Аіяльність як OKУ (зокрема збирати винагороду). Конкурс частково не увінчався успіхом, що зумовило проАовження віАкритого конкурсу Аля визначення акредитованих організацій колективного управміння в указаних вище сферах обов'язкового колективного управління (заяви приймаються Ао 18.07.2019).

Водночас до дати закінчення прийому заяв на участьуконкурсінаакредитаціюувідповідній сфері OKУ (які не перебувають у новому реєстрі ОKУ) мають право збирати винагороду в таких сферах: 
- публічне виконання музичних нелраматичних творів з текстом і без тексту включно з тими творами, що включені до складу аудіовізуальних творів;

- публічне сповіщення музичних неАраматичних творів з текстом і без тексту включно з тими творами, що включені до складу аудіовізуальних творів, крім кабельної ретрансляції;

- репрографічне віАтворення творів і їх частин (уривків);

- відтворення в домашніх умовах і в особистих цілях творів, виконань, зафіксованих у фонограмах, віАеограмах, їх примірниках, а також аудіовізуальних творів і їх примірників.

У цих сферах конкурс ще не оголошено.

Відповідно до ст. 1 Закону України «Про авторське право і суміжні права", публічне виконання - подання творів, виконань, фонограм, передач організацій мовлення шляхом декламації, гри, співу, танцю та іншим способом як безпосередньо (у живому виконанні), так і за допомогою буАь-яких пристроїв і процесів (за винятком передачі в ефір чи по кабелях) у місцях, Ае присутні чи можуть бути присутніми особи, які не належать до кола сім'ї або близьких знайомих цієї сім'ї, незалежно віА того, чи присутні вони в оАному місці й в оАин і той самий час або в різних місцях і в різний час. Тому в цій сфері (сфера публічного виконання музичних творів) Аіючі ОКУ можуть і надалі зАійснювати Аіяльність Ао Аати закінчення прийому заяв на участь у конкурсі на акредитацію у віАповіАній сфері. Конкурс станом на сьогодні ще не оголошено.

Спірним є питання щодо співвідношення таких сфер Аіяльності ОКУ, як право на справеАливу винагороду, спільну Аля виконавців і виробників фонограм (відеограм), за публічне виконання фонограм і зафіксованих у них виконань чи публічну демонстрацію відеограм і зафіксованих у них виконань, опублікованих Аля використання 3 комерційною метою, і публічне виконання музичних неАраматичних творів з текстом і без тексту включно з тими творами, що включені до складу аудіовізуальних творів.

Станом на сьогодні роз'яснень із цього приводу немає.

Звертаємо увагу, що, можливо, в Законі про ефективне управління правами $€$ описка. Так, віАповіАно Ао ч. 3 п. 3 Прикінцевих та ПерехіАних положень Закону, через чотирнадцять місяців з Аня набрання чинності цим Законом Установа оголошує конкурси на визначення акредитованих організацій колективного управління у сфе- рах, передбачених абзацами четвертим і п'ятим частини п'ятої та абзацами четвертим і п'ятим частини шостої статті 11 цього Закону, та розпочинає прийом відповідних заяв віА організацій колективного управління, про що розміщує оголошення на офіційному веб-сайті. Але Закон про ефективне управління правами не містить у ст. 11 цих частин і пунктів. Очевидно, йдеться про ст. 12, а не ст. 11. Із цих же пунктів ст. 12 убачається, що сферами, передбаченими абзацами 4 і 5 ч. 5 та абзацами 4 і 5 ч. 6 ст. 12 цього Закону, є публічне виконання музичних недраматичних творів з текстом і без тексту, включно з тими творами, що включені до складу аудіовізуальних творів; публічне сповіщення музичних недраматичних творів 3 текстом і без тексту, вк^ючно з тими творами, що включені Ао склаАу аудіовізуальних творів, крім кабельної ретрансляції; репрографічне вілтворення творів та їх частин (уривків); віАтворення в Аомашніх умовах і в особистих цілях творів, виконань, зафіксованих у фонограмах, відеограмах, їх примірниках, а також аудіовізуальних творів та їх примірників. Тобто конкурси у цих сферах мають бути оголошені після 22.09.2019 (14 місяців після набуття чинності Законом про ефективне управління правами). Ао часу закінчення строку прийняття заяв за цим конкурсом ОКУ продовжують Аіяти в цих сферах.

Висновки 3 АосліАження та перспективи подальших розвіАок у цьому напрямі. Прийняття закону про ефективне управління правами $\epsilon$ позитивним аспектом щоАО ВАосконалення правового регулювання у сфері колективного управління правами. Суспільство мусить виховувати в собі повагу Ао авторських і суміжних прав творців музичних творів і їх виконавців. Використання саме ліцензійної музики є цивілізованим механізмом використання чужої творчості. "Фонова" музика в закладах громадського харчування, магазинах, салонах, бізнес-центрах тощо створює атмосферу та антураж указаних закладів. Їх власники, безумовно, використовують таку музику Аля створення привабливості своїх закладів, а отже, таке використання віАбувається саме з комерційною метою. Новий закон про ефективне управління правами покликаний налагодити відносини між правовласниками, ОКУ та користувачами музичних творів. Засади і способи використання таких творів, що визначені цим законом, відповідають міжнародним стандартам. Водночас упровадження механізмів, які передбачив законодавець щодо справді ефек- 
тивного Аля правовласників управління правами, потребує часу (кілька років). Про це свідчать і прикінцеві та перехідні положення закону про ефек- тивне управління правами, які передбачають Аосить тривалий процес поступового реформування в цій сфері.

\section{Тарасенко Меонід Меонідович \\ НОВАЦІЇ ЩОАО ЗАІЙСНЕННЯ КОЛЕКТИВНОГО УПРАВАІННЯ МАЙНОВИМИ АВТОРСЬКИМИ ТА СУМІЖНИМИ ПРАВАМИ}

Стаття присвячена аналізу законодавчих новацій щодо зАійснення колективного управління майновими авторськими та суміжними правами. У науковій статті досліджено правове регулювання Аіяльності організацій колективного управління за новим Законом про ефективне управління правами. На основі аналізу положень чинного законодавства визначено, що Закон про ефективне управління правами передбачає новий механізм набуття правового статусу організації колективного управління. Установлено, що станом на сьогодні залишається не Ао кінця визначеним правовий статус Аіючих організацій колективного управління, що породжує неоАнакове правозастосування на практиці щодо можливості суб'єктів господарювання правомірно використовувати музичні твори піА час здійснення господарської діяльності.

Киючові слова: майнові авторські права, суміжні права, організації колективного управління, музичний твір, інтелектуальна власність.

\section{Тарасенко МеониА Меонидович \\ НОВАЦИИ ПО ОСУЩЕСТВАЕНИЮ КОМЕКТИВНОГО УПРАВАЕНИЯ ИМУЩЕСТВЕННЫМИ АВТОРСКИМИ И СМЕЖНЫМИ ПРАВАМИ}

Статья посвящена анализу законодательных новаций по осуществлению комлективного управления имущественными авторскими и смежными правами. В научной статье исслеАовано правовое регулирование деятельности организаций комлективного управления по новому Закону об эффективном управлении правами. На основе анализа положений действующего законодательства определено, что Закон об эффективном управлении правами предусматривает новый механизм приобретения правового статуса организации комлективного управления. Установлено, что на сегодняшний день остается не до конца определенным правовой статус действующих организаций комлективного управления, что порожАает неодинаковое правоприменение на практике относительно возможности субъектов хозяйствования правомерно использовать музыкальные произведения при осуществлении хозяйственной деятельности.

Киючевые слова: имущественные авторские права, смежные права, организации комлективного управления, музыкальное произведение, интеммектуальная собственность.

\section{Tarasenko Leonid}

INNOVATIONS IN THE IMPLEMENTATION OF COLLECTIVE MANAGEMENT OF PROPERTY COPYRIGHT AND RELATED RIGHTS

The article is devoted to the analysis of legislative innovations in the implementation of collective management of property copyright and related rights. The author analyzes the legal regulation of the activities of collective management organizations under the new law on the effective management of the rights. On the basis of the analysis of the provisions of the current legislation, it is determined that the law on effective management of the rights provides for a new mechanism for acquiring the legal status of a collective management organization. The author established that the legal status of the existing collective management organizations remains unclear. This gives rise to unequal enforcement in practice as to the possibility for business entities to legitimately use musical compositions.

The author established that collective management is voluntary, expanded, and compulsory. Voluntary collective management is carried out by a collective management organization solely with respect to the objects of copyright and (or) related rights included to the catalog of this collective management organization. Voluntary collective management of property copyright and related rights can be carried out in any area of the management of rights, except those that have an extended or compulsory collective management. Extended collective management of property rights to objects of copyright and (or) related rights is carried out by a collective management organization, regardless of their availability in the catalog of this organization (except when the corresponding rights have been seized by the right holder from collective management in accordance with the procedure established by law), as stipulated by the Law on effective management of the rights of spheres, carried out by accredited institutions of the Organization in the areas determined by law. Obligatory collective management of property rights to objects of copyright and (or) related rights is carried out by a collective management organization, regardless of their availability in the catalog of this organization. Such organization should also be accredited by the Accreditation Commission in the areas determined by the law.

The author concludes that the adoption of the law on the effective management of the rights is a positive aspect in improving the legal regulation in the field of collective rights management. The use of licensed music is a civilized mechanism for using someone's creativity. The new law on the effective management of the rights is intended to 


\section{0 回回回回回回回回回回回回回回回回回回回回回 Випуск 33}

establish a relationship between the rights holders, the collective management organizations and the users of musical works. The principles and methods of using such works as defined by this law are in accordance with international standards. The introduction of mechanisms foreseen by the legislature on the effective administration of the rights holders takes some time (several years). This is evidenced by the final and transitional provisions of the law on the effective administration of the rights, which provide for a rather long process of gradual reform in this area.

Key words: copyright, related rights, collective management organizations, musical work, intellectual property. 